\title{
Farming different species in RAS in Nordic countries: Current status and future perspectives
}

Dalsgaard, Anne Johanne Tang; Lund, Ivar; Thorarinsdottir, Ragnheidur; Drengstig, Asbjørn; Arvonen, Kaj; Pedersen, Per Bovbjerg

Published in:

Aquacultural Engineering

Link to article, DOI:

10.1016/j.aquaeng.2012.11.008

Publication date:

2013

Link back to DTU Orbit

Citation (APA):

Dalsgaard, A. J. T., Lund, I., Thorarinsdottir, R., Drengstig, A., Arvonen, K., \& Pedersen, P. B. (2013). Farming different species in RAS in Nordic countries: Current status and future perspectives. Aquacultural Engineering, 53, 2-13. https://doi.org/10.1016/j.aquaeng.2012.11.008

\section{General rights}

Copyright and moral rights for the publications made accessible in the public portal are retained by the authors and/or other copyright owners and it is a condition of accessing publications that users recognise and abide by the legal requirements associated with these rights.

- Users may download and print one copy of any publication from the public portal for the purpose of private study or research.

- You may not further distribute the material or use it for any profit-making activity or commercial gain

- You may freely distribute the URL identifying the publication in the public portal 


\section{Accepted Manuscript}

Title: Farming different species in RAS in Nordic countries:

Current status and future perspectives

Authors: Johanne Dalsgaard, Ivar Lund, Ragnheidur Thorarinsdottir, Asbjørn Drengstig, Kaj Arvonen, Per Bovbjerg Pedersen

PII: S0144-8609(12)00092-1

DOI: doi:10.1016/j.aquaeng.2012.11.008

Reference: AQUE 1668

To appear in: Aquacultural Engineering

Received date:

17-9-2012

Accepted date:

19-11-2012

Please cite this article as: Dalsgaard, J., Lund, I., Thorarinsdottir, R., Drengstig, A., Arvonen, K., Pedersen, P.B., Farming different species in RAS in Nordic countries: Current status and future perspectives, Aquacultural Engineering (2010), doi:10.1016/j.aquaeng.2012.11.008

This is a PDF file of an unedited manuscript that has been accepted for publication. As a service to our customers we are providing this early version of the manuscript. The manuscript will undergo copyediting, typesetting, and review of the resulting proof before it is published in its final form. Please note that during the production process errors may be discovered which could affect the content, and all legal disclaimers that apply to the journal pertain. 


\section{Farming different species in RAS in Nordic countries: Current status and future perspectives}

\section{Research highlights}

- Compilation and assessment of data from hard-to-assess literature as well as hand-on experiences with operating RAS in practice

- Description / information on system setup for different species including not formerly published data

- List of water quality parameters for different species observed under general conditions in operating, commercial RAS

- High capital costs are one of the biggest challenges to sustainable RAS calling for large scale intensive productions to reduce investment and operation costs 
Farming different species in RAS in Nordic countries: Current status and future perspectives

\section{Johanne Dalsgaard $^{a}$, Ivar Lund ${ }^{a}$, Ragnheidur Thorarinsdottir ${ }^{b}$, Asbjørn Drengstig $^{c}$, Kaj} Arvonen $^{d}$, Per Bovbjerg Pedersen ${ }^{a}$

a Technical University of Denmark, DTU Aqua, Section for Aquaculture, The North Sea Research Centre, P.O. Box 101, DK-9850 Hirtshals, Denmark. E-mail addresses: jtd@aqua.dtu.dk; il@aqua.dtu.dk; pbp@aqua.dtu.dk

${ }^{\text {b }}$ Svinna-verkfrædi ehf., Fannafold 61, 112 Reykjavik, Iceland. E-mail address: ragnheidurith@gmail.com

${ }^{c}$ Norwegian Lobster Farm AS, Stavanger, Norway. E-mail address: asbjorn.drengstig@hobas.no

${ }^{d}$ Arvotec, Ruukintie 45, FI-79620 Huutokoski, Finland. E-mail address:

kaj.arvonen@careliancaviar.com

*Corresponding author: Technical University of Denmark, DTU Aqua, Section for Aquaculture, The North Sea Research Centre, P.O. Box 101, DK-9850 Hirtshals, Denmark. Tel.: +45 35883216; Fax: +45 35883260; E-mail address: jtd@aqua.dtu.dk 


\begin{abstract}
Recirculating aquaculture systems (RAS) have gained increasing interest in recent years as a means to intensify fish production while at the same time minimize the environmental impact. Considerable hands-on experience has accumulated within the Nordic countries over the last 20-30 years in designing, building, and operating intensive land-based RAS for different species. This study compiles and assesses published literature along with un-published hands-on experiences with rearing different species in RAS in the Nordic countries, including Atlantic salmon (Salmo salar), rainbow trout (Oncorhynchus mykiss), European eel (Anguilla anguilla), pike perch (Stizostedion lucioperca), Arctic char (Salvelinus alpinus), sturgeon (order Acipenseriformes), Nile tilapia (Oreochromis niloticus), and European lobster (Homarus gammarus). High capital costs are one of the biggest challenges to sustainable RAS calling for large scale intensive productions to reduce investment -and operation costs. Consistent with this, production of Atlantic salmon smolts in indoor RAS and rainbow trout in outdoor Model-Trout-Farms (MTFs) have been the commercially most successful productions so far. Aside from end-of-pipe treatment including sludge handling and efficient nitrogen removal, much of the RAS technology applied is well known and is, as such, more or less ready to apply for culturing a variety of species. Successful production of "new" species in RAS therefore largely comes down to identifying the biological requirements of that specific species, and designing the RAS to fulfill and support the specific requirements. Well established brood-stocks and continuous supply of offspring is furthermore a prerequisite for successful RAS production of most species. Successful operations of less intensive RAS such as aquaponic systems appear to be feasible primarily when culturing more exotic species targeted for selected customers.
\end{abstract}

\title{
Keywords: Hands-on experience, Intensive RAS, RAS in operation, Rearing conditions, Water quality
}




\section{Introduction}

While the aquaculture production is expanding rapidly in large parts of the world, it is more or less stagnant or even slightly decreasing in the Nordic countries (Denmark, Faroe Islands, Finland, Iceland, and Sweden) aside from Norway (FAO 2010; FEAP 2011). Part of this is due to differences in natural environmental conditions, with prolonged low temperature periods challenging intensive aquaculture production at high latitudes. Strict environmental regulations, limited access to freshwater, focus on waste water management and animal welfare slows down growth in the industry even further (Martins et al., 2010; Paisley et al., 2010). These issues are, or will soon become, highly relevant in a global context, and there is need for development of cost-effective, economically viable aquaculture production methods that minimize the environmental impact while at the same time ensure optimal rearing conditions.

There is considerable growth potential for land-based intensive recirculating aquaculture systems (RAS) as a means to mitigate these challenges. Intensive RAS make it possible to decrease water consumption and significantly reduce nutrient outlet concentrations through continuous technological improvements and developments. It is possible to control rearing temperatures along with essential water quality parameters such as dissolved oxygen, carbon dioxide, ammonia, nitrite, nitrate, $\mathrm{pH}$, salinity, and suspended solids. This allows maintaining good rearing conditions for optimized growth and feed utilization of a given species. It furthermore allows for a diversification of species that may be cultured in RAS, which is a necessary prerequisite for ensuring a sustainable development of the industry (Le François, 2010). Specific productions for targeted, niche or local markets might provide additional opportunities for sustainable RAS productions.

On the downside to RAS, investment and operational costs are high compared to less intensive systems, and increased technical complexity puts large demands on system management, challenging the profitability of such systems even further. Commercial scale production in RAS is therefore, apart from a few species, still rather limited (Martins et al., 2010). Large scale commercial rearing in RAS in the Nordic countries includes Atlantic salmon smolt (Salmo salar), rainbow trout (Oncorhynchus mykiss), and European eel (Anguilla anguilla), while minor scale commercial productions of, e.g., Arctic char (Salvelinus alpinus), pike perch (Stizostedion lucioperca), and sturgeon (order Acipenseriformes) also takes place. Pilot scale RAS are currently being developed / tested for rearing of Nile tilapia (Oreochromis niloticus) and European lobster (Homarus gammarus), and fry and fingerlings of many different species are produced in RAS.

Considerable hands-on experience has accumulated within the Nordic countries over the last 20-30 years in designing, constructing, and operating intensive land-based RAS. Denmark has been one of the pioneering countries, contributing significantly to the development of both domestic systems 
and RAS technology for export. Within the last 10-15 years, Norwegian companies have specialized in the development of smolt RAS as well as RAS technology for export.

Much of the hands-on experience and existing knowledge concerning RAS setup and issues, such as water quality parameters when rearing different species in practice, have never been published. Moreover, if published the information may be hardly accessible as it is often present in miscellaneous governmental and research institute reports, memorandums, etc. written in different languages. For future growth in the sector, it is imperative to document this experience. Furthermore, it is important to evaluate the performance of different species and systems in order to support species diversification and improve system design and performance. The objective of this study was therefore to exemplify ongoing activities, and to compile and assess existing published literature along with un-published hands-on experiences with rearing different species in RAS in the Nordic countries. Given the heterogeneity of the information, and the production of many species in RAS being in an up-start phase with yet little experience gained, the level of details provided for each species inevitable varies.

Table 1 summarizes water quality parameters observed under general conditions in commercial or pilot scale RAS in operation. The information is largely obtained from farmers / managers, and reflects their experiences with running RAS in practice. The values may deviate from scientifically determined, optimal physiological values published in peer-reviewed journals, as the latter is often based on short-term, single-factor, laboratory scale experiments rather than long-term, large scale, commercial production systems (Colt, 2006).

TABLE 1

\section{Atlantic salmon smolt (Salmo salar)}

\subsection{Current status}

Atlantic salmon is the most produced species in the Nordic countries. Norway is by far the largest producer, producing almost 1 million metric tons (MT) in 2010 (FEAP, 2011). There was 214 licensed Norwegian hatcheries in 2009/2010 with an annual production of some 230 million smolts (Drengstig et al., 2011a). Apart from additional production in Iceland and in the Faroe Islands there is only limited production of farmed salmon in other Nordic countries (FEAP, 2011).

Grow-out mainly takes place in net cages at sea, while smolts traditionally have been produced in land-based systems and in cages in lakes (Bergheim et al., 2009; Terjesen et al., 2009). The Faroe Islands had seven smolt producing RAS farms in 2007 (Bergheim et al., 2009), and less than $10 \%$ of Norwegian smolt farms have currently implemented RAS technology. However, many Norwegian 
farmers plan to convert to RAS and most newly constructed Norwegian farms are built as RAS (Drengstig et al., 2011b).

The increased focus on RAS for smolt production in Norway is due to: i) limitations in freshwater resources especially during dry periods of the growing season; ii) problems associated to inlet water quality as most water bodies have relatively soft water (low calcium) requiring liming or silicate to increase alkalinity; iii) need for UV irradiation / ozone treatment for disinfection purposes; iv) need for stripping off high levels of $\mathrm{CO}_{2}$ (ground water); and v) the advantages of constant, optimized temperature conditions offered in RAS in contrast to open systems (Kristensen et al., 2009). The latter allows a faster and more flexible all year round production, i.e., including also cold seasons. By utilizing RAS technologies, smolts can be ready for on-growing in sea cages in spring, summer, and autumn. Furthermore, while smolts previously were grown to a size of $30-50 \mathrm{~g}$, and lately to $140-170$ $\mathrm{g}$ before stocking into net cages (Bergheim et al., 2009), future plans are to grow them even larger (250-1,000 g) on land. Doing so will reduce the overall production time (rearing under highly controllable conditions), reduce problems with sea lice (Lepeophtheirus salmonis) infestation (smaller juveniles being particularly vulnerable), and expand the production area as most of the well suited sites at sea / in fjords are already utilized.

\subsection{Rearing conditions}

There are many different commercial feed types available optimized for Atlantic salmon smolt, and feed conversion ratios (FCR) are generally low, i.e., around 0.7-0.8 (Hevrøy et al., 2004; Opstvedt et al., 2003).

Optimal water quality requirements and safety levels in smolt farms have been described by Bergheim et al. (2009) and are listed in table 1. The required heat sum from fertilization to hatching is approximately 500 day-degrees, while additional $2500-4000$ day-degrees are required to reach smoltification (Lekang, O.-I., 2008). Smoltification can be "scheduled" according to production plans by controlling and optimizing light -and temperature regimes.

Studies indicate that smolts reared in RAS grow better and have a higher survival rate after transfer to sea cages than traditionally reared smolts (Terjesen et al., 2009). This may relate to the optimized temperature conditions in RAS and consequently larger smolts being produced before transfer to sea.

Recent expansions in the smolt industry have resulted in a significant increase in fish densities in many systems, necessitating the use of pure oxygen. Concomitant with this, $\mathrm{CO}_{2}$ concentrations have increased reaching levels up to $40 \mathrm{mg} / \mathrm{L}$ (Martens et al., 2006). Peak density in the systems typically occurs just prior to transfer to sea with the risk of critical $\mathrm{CO}_{2}$ levels reducing initial growth in sea cages. Carbon dioxide levels should preferably not exceed $15-20$ mg/L (Fivelstad et al., 1999, 
2003), and high levels may be avoided through the use of $\mathrm{CO}_{2}$ stripping in tanks or by specific filters in RAS. More than one third of Norwegian farmers have installed equipment for stripping of $\mathrm{CO}_{2}$ either as part of the water intake or within the system (Bergheim et al., 2009). In the Faroe Islands, a recent shift from flow-through systems to RAS including efficient $\mathrm{CO}_{2}$ removal technology improved the water quality considerably, and smolt mortality has been reduced from $20 \%$ to less than $5 \%$ of the biomass (Joensen, 2008).

\subsection{Existing RAS setups}

Most smolt farms employ either single pass flow-through systems (with oxygenation), partial reuse systems (with aeration, oxygenation, and particle removal), or RAS (Bergheim et al., 2009). As mentioned in section 2.1, the number of Norwegian smolt RAS farms are increasing rapidly but information on how these systems affect performance and welfare in the salmon production industry, as well as their environmental impact, is fragmented (Terjesen et al., 2009). Most Nordic salmon RAS with biofilters use circular tanks, microscreen filtration, and oxygenation technologies to increase carrying capacity. Moving bed biofilters appear to be preferred to fixed bed biofilters and trickling filters (Drengstig, 2011b). Moving bed biofilters are often more compact, use media with a larger specific surface area $\left(500-800 \mathrm{~m}^{2} / \mathrm{m}^{3}\right)$, do not require back-washing, and are generally considered easier to operate and maintain than fixed bed biofilters. A maximum feed loading of $2 \mathrm{~kg}$ feed $/ \mathrm{m}^{3}$ make-up water is typically applied (Bjarne Hald Olsen, Billund Aquaculture, pers. comm.), and Fivelstad et al. (2003) found that smolts of 100-200 g can be produced with a make-up water intake of $0.02-0.04 \mathrm{~L} / \mathrm{min} / \mathrm{kg}$ fish at $10-12^{\circ} \mathrm{C}$. Smolts are typically feed round the clock (24 h light conditions) using automatic feeding systems.

A recently developed concept, based on a combination of smolt production and on-growing of market size Atlantic salmon in land-based RAS using seawater, is currently being implemented in Denmark. Here, a full-scale, land-based RAS (1,000 MT/year) integrates all production units needed for full life-cycle salmon production, i.e., an incubation unit, a separate RAS hatchery, a RAS smolt unit, and a grow-out RAS unit. The latter consists of four $\varnothing 10 \mathrm{~m}$ tanks and four $\varnothing 17 \mathrm{~m}$ tanks. Four additional $\varnothing 10 \mathrm{~m}$ tanks are included for harvesting and purging potential off-flavor substances.

\subsection{Future challenges and perspectives}

Several new approaches are likely to be implemented within the salmon smolt industry in the coming years to improve overall processes and reduce investment and operation costs. In Norway, it is anticipated that 6-8 new, intensive RAS will be built each year along with reconstruction of existing flow-through systems into reuse systems (Drengstig et al., 2011a). The overall plan is to develop larger RAS farms as the industry currently experiences a deficit of smolts. Capacity building is of high 
priority given that the Norwegian salmon industry aims at an annual production of 2 million MT to be reached within the coming 10 years. Depending on the experiences with system operation and the economy achieved within the coming years, production of $1,000 \mathrm{~g}$ smolts as well as of market sized fish (3-5 kg) in RAS may contribute to achieving this goal.

\section{Rainbow trout (Oncorhynchus mykiss)}

\subsection{Current status}

Next to Atlantic salmon, rainbow trout is the most produced species in the Nordic countries with a total production in 2010 of 105,600 MT (FEAP, 2011). Most of the production has until recently taken place in freshwater, land-based, traditional flow-through systems and in seawater net cages. An increasing number of especially Danish freshwater farms are, however, being reconstructed into so-called Model-Trout-Farms (MTFs), a concept that is characterized by the implementation of different cleaning devices and central elements from recirculation technology. By doing so, the farmers obtain operational advantages and can at the same time increase their production while still complying with a strict, national environmental legislation and new requirements related to implementation of the EU Water Framework Directive (WFD; Directive 2000/60 EC of the European Parliament and of the Council of 23 October 2000).

A comprehensive, 2-years monitoring program was carried out on eight MTFs with the aim of documenting their cleaning efficiency of $\mathrm{N}, \mathrm{P}$, and organic matter and the resulting discharge (Svendsen et al., 2008). Results showed that the MTFs were very efficient in removing N, P, and organic matter, and the specific discharge of nutrients $(\mathrm{kg} / \mathrm{MT}$ fish produced) was concomitantly reduced (table 2 ).

TABLE 2

The Danish legislation was subsequently revised, and Danish trout farmers can now be regulated according to maximum nutrient emissions rather than fixed yearly feed quotas (Danish Ministry of Environment, 2012).

Total investment costs for completely rebuilding a traditional flow-through farm into a MTF are relatively high (approximately 2,800 €/MT produced/year). Rainbow trout is a low / medium value species, but given the new legislation there is no longer any upper limit to the amount of feed that a farmer may apply, and hence to the amount of fish that may be produced, as long as permitted nutrient emissions are not exceeded. As a consequence, there are now strong legislative incentives 
for farmers to continuously improve and optimize system performance and effluent treatment systems in order to produce more fish and improve the return of their investments.

\subsection{Rearing conditions}

There are many different commercial feed types available optimized for rainbow trout including diets targeting on-growing in RAS, and feed conversion ratios are generally good. An average FCR of 0.91 (ranging from 0.80 to 1.05 ) was achieved at the eight MTFs discussed in section 3.1, rearing fish (>50 g) at densities close to $50 \mathrm{~kg} / \mathrm{m}^{3}$.

It typically takes 7-8 months to grow rainbow trout from $20 \mathrm{~g}$ to $300 \mathrm{~g}$ (portion size) in MTFs. However, the actual growth rate depends on the water temperature which, unlike indoor RAS, may vary considerably. Hence, although yearly temperature fluctuations in MTFs usually are less than those observed in open flow-through systems, extremes of 1.6 and $21.0^{\circ} \mathrm{C}$ (winter versus summer) have been observed (table 1). The all year average temperature measured at the eight MTFs was $10.6^{\circ} \mathrm{C}$ (Dansk Akvakultur, 2008), whereas the groundwater temperature (i.e., MTF intake water) in Denmark is around $7-8^{\circ} \mathrm{C}$.

Water quality parameters within the recirculation flow differed both between as well as within the eight monitored MTFs (Svendsen et al. 2008), representing the most intensive type MTFs (see section 3.3). Total ammonia nitrogen (TAN) averaged $2.4 \mathrm{mg} / \mathrm{L}$ (average $\mathrm{min} / \mathrm{max}$ concentrations of 0.3 and $7.5 \mathrm{mg} / \mathrm{L}$, respectively), and according to the farmers, this concentration did not cause any problems to the fish at the observed $\mathrm{pH}$ (averaging 7.8). $\mathrm{NO}_{2}-\mathrm{N}$ averaged $0.15 \mathrm{mg} / \mathrm{L}$ (average $\mathrm{min} / \mathrm{max}$ concentrations of 0.1 and $1.7 \mathrm{mg} / \mathrm{L}$, respectively), and $\mathrm{NO}_{3}-\mathrm{N}$ averaged $7.2 \mathrm{mg} / \mathrm{L}$. The organic matter content was low to moderate compared to intensive RAS in general (Pedersen et al., 2012), with $\mathrm{BOD}_{5}$ and COD levels averaging 4.5 and $25 \mathrm{mg} / \mathrm{L}$, respectively. The concentrations were consistent with the good feed conversion generally obtained and indicate an efficient removal of particulate matter (Dalsgaard and Pedersen, 2011). Furthermore, the modest feed loading applied at the eight MTFs (averaging $0.21 \mathrm{~kg}$ feed $/ \mathrm{m}^{3}$ make-up water) contributed to maintaining moderate organic matter values given a correlation between feed loading and COD concentrations in RAS (Pedersen et al., 2012).

\subsection{Existing RAS setups}

Feeding in MTFs is typically carried out using demand feeders or feeding continuously during daylight hours using various automatic feeding systems.

Two types of MTFs are described in the new Danish legislation (Danish Ministry of Environment, 2012), referring to farm size prior to regulation by emission concentrations. Farms applying more than $230 \mathrm{MT}$ feed/year represent the highest degree of innovation, have the highest feed loading $(\geq$ 
$0.21 \mathrm{~kg} \mathrm{feed} / \mathrm{m}^{3}$ make-up water), the highest degree of recirculation ( $\left.\geq 95 \%\right)$, and use ground -or drain water. In comparison, MTFs applying between 25 and 230 MT feed/year may continue to pump in water from the nearby stream, may apply a lower feed loading $\left(\geq 0.04 \mathrm{~kg} f e e d / \mathrm{m}^{3}\right.$ make-up water), and may apply a lower degree of recirculation ( $\geq 70 \%)$.

The use of groundwater reduces problems in maintaining biosecurity compared to using (untreated) surface water. Furthermore, it ensures that year round temperature fluctuations are reduced, minimizes the risk of introducing diseases into the system, and eliminates the risk of bringing in polluted or poor quality water from the stream.

Raceways and self-cleaning circular tanks made in concrete are used. Raceways are equipped with airlift pumps to pump and aerate the water. Decentralized sedimentation zones (typically in the form of sludge cones) are applied for removal of particulate matter. Sludge is pumped to sludge basins for sedimentation at least twice a week to reduce breakdown and mineralization (Pedersen et al., 2008). Raceways may be equipped with drum filters (typically $\leq 74 \mu \mathrm{m}$ mesh size) following the sedimentation zone for removal of fine particulate matter before the water passes a biofilter. Both fixed bed biofilters (bioelements typically having a specific surface area between $200-750 \mathrm{~m}^{2} / \mathrm{m}^{3}$ ) and moving bed biofilters (media typically having a specific surface area of $750 \mathrm{~m}^{2} / \mathrm{m}^{3}$ ) exist. Fixed bed biofilters must be back-washed at least once a week to remove particulate matter and reduce the heterotrophic biomass in order to enhance nitrification processes (Jokumsen and Svendsen, 2010; Svendsen et al., 2008). In addition, optimal biofilter management requires careful monitoring and adjustment of alkalinity, $\mathrm{pH}$, and dissolved oxygen concentrations.

End-of-pipe treatment of outlet water from the production units and overflow from sludge basins is carried out by constructed wetlands typically comprising the old earthen ponds from the former flow-through system. Ponds are interconnected to form a meandering stream to optimize the processes involved. A certain residence time in the constructed wetland is needed for efficient nutrient removal, including degradation of organic matter, denitrification, and removal of phosphorus through sedimentation and binding and incorporation into microbial biomass (Svendsen et al., 2008). The minimum size of the constructed wetland must be at least 40 or $25 \mathrm{~m}^{2} / \mathrm{MT}$ feed/year in MTFs applying 25-230 or > 230 MT feed/year, respectively. Furthermore, the hydraulic retention time must be at least 12 or $36 \mathrm{~h}$ in MTFs applying $25-230$ or $>230 \mathrm{MT}$ feed/year, respectively (Danish Ministry of Environment, 2012).

Sludge basins must be emptied regularly and $\mathrm{FeCl}$ or $\mathrm{AlCl}$, often in combination with different polymers, may be applied to increase phosphorus precipitation. Geotubes ${ }^{\circledR}$ may be used for sludge dewatering. 


\subsection{Future challenges and perspectives}

Model-Trout-Farm operation costs can be higher than that of traditional flow-through farms, and efficient management requires well educated staff. The farms must be constantly optimized and operated accordingly to ensure a permanently high production for economic viability. The removal efficiency of nitrogen, which is lower than that of phosphorus and organic matter (cf. table 2), is currently the major challenge to MTFs, largely preventing them from further increasing their production. Cost-efficient ways of improving nitrogen removal by denitrification are therefore needed.

The commercial success of MTFs has induced renewed interests in exploring the potential and economic viability of farming rainbow trout in so-called FREA systems (fully recirculation systems), defined as systems having a degree of recirculation of at least 99\% (Dansk Akvakultur, 2007). Although fully feasible from a technical point of view, new challenges may arise in such systems including, e.g., accumulation of harmful substances that may impair fish growth and welfare (e.g., Martins et al., 2009). Furthermore, calculations on economic feasibility seem to render FREA systems for trout production barely possible. However, market prices and variations in costs associated with the production and other related costs might, at some point, change in favor of production in FREA. In such a situation, farms based on the already existing recirculation technology may quickly be established.

\section{European eel (Anguilla anguilla)}

\subsection{Current status}

Intensive farming of European eels started in the 1970s and was further developed during the 1980s when FREA technology was introduced. Denmark played a leading part in the development of this technology for eel, and still has a forefront position within commercial RAS eel farming among the Nordic countries. There were eight commercial eel farms in Denmark in 2011 with a total annual production of approximately 1500 MT (Christian Graver, Danish Eel Producer Association, pers. comm.). In addition, there have been a few commercial eel farms in Norway and Sweden of which one in Sweden is still in operation.

Recruitment of glass eels to the European coast has declined severely in the last decades, and it is estimated that current recruitment is 1-9\% of the recruitment observed in the 1970s (ICES, 2009a). The sharp decline is an effect of a serious eel stock decline probably related to high fishing efforts, loss of habitats, parasitic infections, and possible accumulation of PCBs and other contaminants (ICES, 2009b). European eel was listed in CITES (the Convention on International Trade in Endangered Species of Wild Fauna and Flora) Appendix II in 2007, with regulations coming into force 
in 2009. This means that any import / re-export of live eels or processed eel products requires a CITES import / export permit. A European recovery plan was developed in 2007 (EU, 2007), and the International Council of the Seas (ICES) later stated that recruitment had come to a historical low level (ICES, 2009a). Growing demands by NGOs subsequently resulted in a boycott of eel and eel products from various retailers in Denmark, Germany, and Holland.

Prices on glass eels have recently risen and range at present between 520 and $650 € / \mathrm{kg}(1 \mathrm{~kg}$ corresponding to approximately 2800-3300 individuals). In comparison, prices on market sized eels varied from 7.00 to $9.35 € / \mathrm{kg}$ in January 2010 - 2012 (Christen Graver, Danish Eel Producer Association, pers. comm.).

\subsection{Rearing conditions}

On-growing European eels are typically reared at densities exceeding $120 \mathrm{~kg} / \mathrm{m}^{3}$ (yielding up to 300 $\mathrm{kg} / \mathrm{m}^{2} /$ year), and optimum temperature requirements range between $23-28{ }^{\circ} \mathrm{C}$. The species show relatively wide plasticity with respect to acceptable $\mathrm{pH}, \mathrm{NH}_{4}-\mathrm{N}$, and $\mathrm{CO}_{2}$ levels (table 1 ), all of which makes it very suitable for intensive RAS farming.

Juvenile and on-growing eel RAS systems may be designed similarly, but the stocking density of elvers (i.e., glass eels that have metamorphosed into adult like eels) should not exceed $25 \mathrm{~kg} / \mathrm{m}^{3}$ (McCarthy et al., 1996). The survival from glass eel to pre-adult stages is typically very high (85-90\%; Buchman et al., 2011).

Regular grading improves growth given high individual differences in growth rate and development of hierarchies (Garcia-Gallego and Akharbach, 1998). Quarantine RAS systems are typically stocked with wild caught glass eels at densities of $0.2-0.3 \mathrm{~kg} / \mathrm{m}^{2}$ (Huertas and Cerda, 2006). They are usually fed on cod roe and gradually weaned on to granulated, extruded dry feed (0.3-0.8 mm). They are subsequently sorted and reared to market size (200-400 g) on extruded pellets (1-2.5 mm). Belt feeders are typically used for smaller eels, while demand feeders or electrical feeders are used for larger eels. Eels are typically fed continuously for 8-10 h/day. Feed utilization improves by small meals followed by resting periods and stomach excretion (Mortensen, 1996; Seymour 1989). It takes on average 1.5 to 2 years to grow glass eels to market size.

\subsection{Existing RAS setups}

All European eel farms are based on RAS using FREA technology. Design and management practices vary from system to system. Both raceways, circular, and rectangular tanks exist. Tank design is of minor importance for self-cleaning in comparison to water flow and fish density. A daily water renewal (make-up water) of 4-8\% of the system volume is typically applied, corresponding to feed loadings of $10-20 \mathrm{~kg}$ feed $/ \mathrm{m}^{3}$ make-up water. Most RAS systems use mechanical drum filters with 
40-80 $\mu \mathrm{m}$ mesh size for removal of suspended solids combined with submerged fixed bed biofilters (bioelements having a specific surface area between 150-250 $\mathrm{m}^{2} / \mathrm{m}^{3}$ ), and / or trickling filters for nitrification. Specific inline denitrification filters and phosphorus flocculation technology exist on a few intensive farms.

\subsection{Future challenges and perspectives}

Eel farming is capture-based with supply of juvenile based entirely on glass eels caught in the wild as the reproduction cycle of European eel has not yet been disclosed. An ongoing international research project (PRO-EEL) supported by the European Union through FP7 aims at breeding European eel in captivity (Tomkiewicz et al., 2012).

\section{Pike perch (Stizostedion lucioperca)}

\subsection{Current status}

Rearing of pike perch in extensive systems and ponds has existed for decades throughout Europe, while farming of pike perch in RAS is a relatively new industry. In Denmark, commercial intensive rearing of this species was initiated based on research projects financially supported by EFF (European Fisheries Fund), investigating the biological and technical challenges of rearing this species in RAS (Martin Vestergaard, Aquapri A/S, pers. comm.; Steenfeldt and Lund, 2008; Steenfeldt et al., 2010). Denmark has a few commercial pike perch RAS farms whereas the species is not reared commercially in RAS in other Nordic countries. A few commercial farms relying on recirculation technology exist in other parts of Europe.

\subsection{Rearing conditions}

Pike perch is a true piscivorous species with a high protein requirement. The feed applied is therefore rich in protein (typically $\geq 48 \%$ ) and usually low in fat. The optimal ratio between digestible protein and digestible energy (DP:DE) has, however, not yet been established and no commercial feed is currently available.

Optimum growth rates and feed utilization require rearing temperatures of $22-25^{\circ} \mathrm{C}$, economically favoring closed, indoor RAS to outdoor facilities in which the fish typically grow more slowly (Steenfeldt et al., 2010). It takes on average 460 days to grow a pike perch from $1 \mathrm{~g}$ to $1 \mathrm{~kg}$ in RAS (Martin Vestergaard, Aquapri A/S, pers. comm.).

There is currently rather limited information on water quality parameters for pike perch in operating intensive RAS (table 1). The species appears to be quite robust to low oxygen concentrations, but it is recommended to keep oxygen levels above $50 \%$ saturation in rearing tank outlets to sustain 
growth and optimal biofilter performance. Juvenile and on-growing pike perch are reared in freshwater but tolerate brackish water, while larvae cannot survive salinities above approximately 5 ppt (Lozys, 2004). There are no published studies on the effects of salinity on pike perch performance in RAS.

Optimal light intensities during on-growing are below 10 lux (Luchiari et al., 2006), and abrupt changes in light intensity should be avoided to minimize severe stress and consequently loss of fish. The dim light requirements may interact with daily management routines and inspection of the RAS. Small juveniles (10-50 g) should be kept at densities below $15-30 \mathrm{~kg} / \mathrm{m}^{2}$ (Steenfeldt et al., 2010), while larger juveniles $(0.05-2.0 \mathrm{~kg})$ can be kept at higher densities $\left(30-60 \mathrm{~kg} / \mathrm{m}^{2}\right)$ without any obvious increase in crowding stress parameters, suppressed growth, or increase in FCR (Steenfeldt et al., 2010).

Successful brood-stock (preferably cultured rather than wild) maturation and spawning can be obtained through adequate light -and temperature regulation combined with induced fish behavior (Martin Vestergaard, Aquapri A/S, pers. comm.), eliminating the need for hormonal treatment and artificial fertilization techniques (Steenfeldt and Lund, 2008). Each recirculation unit might preferably be individually adjustable to prolong the spawning season in order that mature spawners can be obtained throughout the year. This ensures a continuous production strategy involving year round stocking and harvesting of fish. Second time spawners (i.e., 3 years of age) provide eggs / semen of better quality than first time spawners (Martin Vestergaard, Aquapri A/S, pers. comm.), and eggs solely from hatchery reared brood-stocks can now be obtained, providing eggs all year round. Several independent brood-stock RAS minimize the risk of outbreak and spreading of diseases. Hatchery conditions and larval management has been described in detail by Steenfeldt and Lund (2008) and Steenfeldt et al. (2010).

\subsection{Existing RAS setups}

The high rearing temperature of pike perch increases energy costs associated with cleaning and operation of recirculation pumps, or alternatively, increases costs associated with installation and operation of heat pumps or heat exchangers.

Recirculating systems for pike perch typically include mechanical filters (40-80 $\mu \mathrm{m}$ mesh size), submerged biological filters, and / or trickling filters for sludge removal and nitrification, respectively. Both fixed bed and moving bed filters exist (specific surface area of the media typically ranging between $150-750 \mathrm{~m}^{2} / \mathrm{m}^{3}$ ). Furthermore, filters for denitrification may be installed as in other FREA systems for finfish farming. Tanks may be rectangular or circular for all production sizes. However, pike perch are relatively shy and easily stressed (Martin Vestergaard, Aquapri A/S, pers. comm.), and tanks should therefore not be too small ( $\varnothing 3-8 \mathrm{~m}$ ) or shallow ( $\geq 1.5 \mathrm{~m})$. In addition, sharp 
edges or obstacles inside the tanks should be avoided as fish might easily get injured during situations of acute stress behavior.

Automatic feeders ensure the best feed intake by pike perch in RAS. It may be advantageous to use floating pellets to ensure a more uniform feed distribution and improve management (i.e., optimize estimates of feed consumption and avoid overfeeding) (Steenfeldt et al., 2010). However, juveniles $(<5 \mathrm{~g})$ must be weaned using floating pellets, as they might otherwise not accept them at later stages (Martin Vestergaard, Aquapri A/S, pers. comm.).

Separate units of smaller on-growing RAS compared to a few larger units are advantageous in terms of daily management procedures, cleaning and disinfection, as well as maintenance and operation of biofilters (Martin Vestergaard, Aquapri A/S, pers. comm.). Using several separate systems furthermore ensures that pike perch from different cohorts and of different sizes can be kept apart, minimizing stress during grading, water treatment, etc. As a rule of thumb, pike perch should be graded (from $1 \mathrm{~g}$ onwards) at every doubling of the body weight to ensure a more uniform growth.

\subsection{Future challenges and perspectives}

Year round production of pike perch requires constant high temperatures, which is only feasible in intensive RAS. In the design of new RAS for this species, and to make the production economically sustainable, focus should be on cost reductions (i.e., investment and operational costs, fingerling expenses, energy costs, maintenance, etc.) as well as on improving growth and feed utilization. Furthermore, establishment of breeding or domestication programs might support commercial viability of pike perch farming.

\section{Arctic char (Salvelinus alpinus)}

\subsection{Current status}

Arctic char is a highly valued salmonid species renowned for its good texture and taste (Gunnarsson, 2006) and a fillet yield exceeding that of rainbow trout (Glandfeld, 1993). Arctic char farming is still a kind of niche industry with a global, annual production of about 5,000 MT of which approximately $60 \%$ takes place in Icelandic flow-through systems (Oddsson and Steindorsson, 2009). Minor productions take place in Norway, Sweden, and Canada some of which are in RAS, and there is increasing interest for farming Arctic char in Chile and Australia (Gunnarsson, 2006; Molleda, 2007; Oddsson and Steindorsson, 2009). The production of Arctic char in Iceland is expected to double within the next few years driven by increasing market demands, and the industry is anticipated to grow even further in the future. 
Arctic char is sold as whole or fully trimmed fillets, either fresh or frozen. The main markets are located in Europe (mainly Switzerland) and in the United States. Current wholesale prices for fillets are about $10-13 € / \mathrm{kg}$.

\subsection{Rearing conditions}

Arctic char is the most cold-adapted salmonid species (Johnson, 1980) with an optimal rearing temperature between $5-12^{\circ} \mathrm{C}$. The optimum rearing temperature for juveniles is slightly higher (8-15 ${ }^{\circ} \mathrm{C}, 20-500 \mathrm{~g}$ ), although the growth advantages obtained when rearing at elevated temperatures $\left(15^{\circ} \mathrm{C}\right)$ appear to be lost when producing fish $>1000 \mathrm{~g}$ due to maturation and subsequent growth reduction (Gunnarsson et al., 2011; Ragnheidur Thorarinsdottir, pers. comm.). Arctic char typically reaches market size 15-30 months post-hatch depending on the rearing temperature and slaughtering size (800-1,300 g). It tolerates densities up to $130 \mathrm{~kg} / \mathrm{m}^{3}$ (Summerfelt et al., 2004), and is therefore considered very suitable for rearing in cold-water intensive RAS, where constant yearround rearing temperatures can be maintained (Siikavuopio et al., 2009). There is, however, rather limited information on water quality parameters for the species in operating intensive RAS (table 1). Arctic char does not feed as aggressively as for example rainbow trout and multiple daily feeding events are necessary to optimize the feed intake (Linnér and Brännäs, 2001). Several commercial fish feed companies produce diets formulated specifically for Arctic char.

\subsection{Existing RAS setups}

Abundant sources of freshwater, seawater, and geothermal heat provide unique conditions for landbased aquaculture in Iceland, and Icelandic land-based farms have so far not invested in RAS. Most Icelandic farms use geothermal heat to maintain optimal rearing temperatures and reduce water consumption by adding oxygen to the inlet water. Some farms reuse water after removing suspended solids by simple filtration.

Compared to the production of Arctic char in flow-through or partial-reuse systems as in Iceland, rearing of this species in intensive RAS is still in its infancy and very few systems exist. Summerfelt et al. (2004) provided a thorough description of some intensive North American grow-out RAS including both commercial -and demonstration facilities, and Siikavuopio et al. (2009) and Skybakmoen et al. (2009) provided thorough descriptions of a commercial Norwegian Arctic char RAS.

The systems described have a high degree of recirculation ( 95\%) and use self-cleaning, circular ('Cornell-type' dual-drain) or octagonal culture tanks attached with sludge collectors for rapid and efficient solids removal, thereby reducing mineralization and concomitant deterioration of the water quality (Summerfelt et al., 2004). Furthermore, outlet water from the culture tanks passes through microscreen drum filters to ensure high water quality (Summerfelt et al., 2004). Pumping rates 
should be high enough to exchange the culture tank volume once every 30-45 min, thereby maintaining safe dissolved oxygen concentrations at high fish densities (Johannsson et al., 2010; Summerfelt et al., 2004). The low rearing temperature of Arctic char can be a challenge in RAS as the degree of recirculation increases, and may require installation of water chillers or increased use of make-up water to maintain the temperature within the optimal range (Summerfelt et al., 2004). The North American grow-out systems described by Summerfelt et al. (2004) primarily use fluidized sand biofilters, which are relatively inexpensive and have a high specific surface area $(8,000-12,000$ $\mathrm{m}^{2} / \mathrm{m}^{3}$ ). These biofilters are efficient in removing TAN and oxidizing nitrite with typical outflow concentrations of TAN between 0.1-0.5 mg/L and $\mathrm{NO}_{2}-\mathrm{N}$ less than 0.1-0.3 mg / $\mathrm{L}$. In comparison, the Norwegian grow-out system described by Skybakmoen et al. (2009) uses a trickling biofilter. This type of biofilter needs a high hydraulic flow-through (pumps working at $472 \mathrm{~L} / \mathrm{min} / \mathrm{m}^{2}$ ) to maintain stable nitrification rates due to the short contact time in the filter. UV irradiation units or addition of ozone prior to culture tanks may be used to maintain low levels of suspended solids and $\mathrm{NO}_{2}-\mathrm{N}$ $(<0.01 \mathrm{mg} / \mathrm{L})$ in the rearing tanks (Summerfelt et al., 2004).

\subsection{Future challenges and perspectives}

Most of the existing RAS technology and knowhow has been developed for rearing species at higher temperatures than Arctic char and / or for rearing other salmonid species. More research and development is therefore needed to ensure optimal rearing conditions for the species, although significant improvements have already been achieved (Summerfelt et al., 2004). In addition to system optimization, there is a need for systematic breeding programs and broodstock development selecting for fast growing strains. Wild caught fish are generally not suitable for on-growing in intensive RAS due to high mortalities (often due to various pathogens) and seasonal changes in growth and feed utilization, a trait that is typically not observed in hatcheries producing Arctic char (Siikavuopio et al., 2009; Skybakmoen et al., 2009). Furthermore, there have been problems with early sexual maturation, reducing growth rates and fillet quality before specimens reaching market size (Summerfelt et al., 2004). An Icelandic breeding program was initiated in 1989 at Holar (Svavarsson, 2007) with emphasis on growth, sexual maturation, and resistance against pathogens. In 1991, the Icelandic company Stofnfiskur similarly started a breeding program (Gunnarsson, 2006) with support from the Icelandic Ministry of Agriculture and Fisheries, and results from this ongoing work has been promising (Oddsson and Steindorsson, 2009). 


\section{Sturgeon (order Acipenseriformes)}

\subsection{Current status}

Sturgeon (order Acipenseriformes) comprises more than 20 different species and a wide number of hybrids (Bronzi et al., 2011; Litvak, 2010). It is among the most valuable group of fish because of caviar, but the meat quality can also be quite high (Bronzi et al., 2011; Köksal et al., 2000). Sturgeons are, however, also among the most endangered group of fish due to overfishing, poaching, pollution, damming, habitat deterioration, etc. (Bronzi et al., 2011; Jaric and Gessner, 2012; Litvak, 2010). Since 1998, all extant species including those commercially reared have been listed in CITES Appendix I or II (i.e., threatened by extinction or in risk of becoming so), and trade of fish from the group has since been regulated under CITES.

Aquaculture production of sturgeon started in the 1960s in the former USSR (farming 'bester' - a hybrid between Huso huso and Acipenser ruthenus), while farming in Iran, North America, and Europe was initiated in the 1980s (Bronzi et al., 2011; Jaric and Gessner, 2010; Williot et al. 2001). Production took off in the beginning of the twenty-first century with China entering the industry, and the country currently accounts for approximately $75 \%$ of the global sturgeon meat production (Bronzi et al., 2011). Siberian sturgeon (A. baerii) is the most commonly reared species, but at least 12 species and 6 hybrids are farmed in more than 30 countries (Bronzi et al., 2011). The global production of caviar was estimated to be 110-120 MT in 2008 (close to the legal yield from fisheries), but has most likely increased considerably since then. In a foreseeable future, most caviar is anticipated to come from aquaculture. The most rare, top quality Beluga caviar sells for more than $10,000 € / \mathrm{kg}$, while caviar from commercial production sells for about $10 \%$ of this price (Bronzi et al., 2011).

Sturgeons are relatively easy to rear, and species cultured for production of meat could be potential candidates for substituting other commonly reared species such as rainbow trout (Köksal et al., 2000). On-growing may take place in flow-through raceways, tanks, earthen ponds, or in RAS (Paschos et al., 2008; Williot et al., 2001). Finland is currently the only Nordic country commercially engaged in sturgeon aquaculture, and farming of sturgeon in recirculation modules has taken place here since 2005 . Sturgeon meat has been sold since 2007 at prices of 5-7 $€ / \mathrm{kg}$, while actual caviar production based on farming in RAS started in 2011.

\subsection{Rearing conditions}

Sturgeons are generally slow growing, late maturing fish. It takes for example 5-6 years for male and 6-8 years for female Siberian sturgeon to reach maturity in captivity, which is still far earlier than in the wild (FAO, 2012; Rachek et al., 2010; Williot et al., 2001). Sturgeons are reared in freshwater 
throughout their life-cycle despite some species being semi-anadromous (Williot et al., 2001). They generally tolerate high densities (up to $80-90 \mathrm{~kg} / \mathrm{m}^{3}$ for fish weighing $10 \mathrm{~kg}$; Kaj Arvonen, Arvotec, pers. comm.), and show plasticity with respect to temperature and oxygen levels (table 1) (Williot et al., 2001; Litvak, 2010). Water quality requirements are largely equal to that of other species, although they appear to be more sensitive to $\mathrm{NO}_{3}-\mathrm{N}$ (Kaj Arvonen, Arvotec, pers. comm.). A rearing temperature of $20^{\circ} \mathrm{C}$ appears to be suitable for on-growing, although slightly higher temperatures speed up the maturation process.

Sturgeons are bottom feeders and commercial diets formulated for sturgeon are readily available. Rearing conditions and feeding rates in farming aimed at caviar production must be carefully adjusted to maturate fish with optimal timing and to obtain high quality caviar, which is valued according to color, firmness, fat content and taste. Caviar yields are typically about $10-15 \%$ of total body weight, while fillet yields are about 40-50\% (Litvak, 2010; Williot et al., 2001). Hatchery conditions and brood-stock management is generally well known and has been described for a few species (e.g., Hamlin et al., 2006; Litvak, 2010; Paschos et al., 2008; Williot et al., 2001).

\subsection{Existing RAS setups}

Caviar-oriented production requires extensive facilities for keeping enlarging stocks. A high intensive RAS facility in Finland, rearing both Siberian sturgeon (A. baerii) and Beluga (Huso huso), is located within a paper mill using waste heat from the plant to heat the water. The facility consists of several separate modules each with their own recirculation system and each with a high degree of recirculation (99.5\%). Sludge is collected centrally from the circular tanks, and tank outlet water is passed through drum filters ( $60 \mu \mathrm{m}$ mesh size). Sludge is treated at the waste water treatment plant associated with the paper mill. Water is degassed by aeration prior to being pumped through fluidized sand-bed biofilters with a high specific surface area (typically $8,000-12,000 \mathrm{~m}^{2} / \mathrm{m}^{3}$ ), and runs by gravity to oxygenation and ozone towers before returning to the tanks. Each module has a volume of $250 \mathrm{~m}^{3}$ and a flow of approximately $100 \mathrm{~L} / \mathrm{s}\left(360 \mathrm{~m}^{3} / \mathrm{h}\right)$, corresponding to a complete module water exchange of 1.4 times $/ \mathrm{h}$. A maximum feed loading of $0.83 \mathrm{~kg}$ feed $/ \mathrm{m}^{3}$ make-up water is typically applied in sturgeon RAS (Bjarne Hald Olsen, Billund Aquaculture, pers. comm.). Rearing conditions in the Finnish facility are controlled using a custom designed feeding system. The system monitors temperature, oxygen, and $\mathrm{pH}$ in each module separately, while all necessary adjustments are made manually to prevent problems arising from potential probe failures. The feeding system furthermore controls the light conditions, and can simulate any season of the year. An alarm system registers any failure or other anomalies in the systems, in which case feeding is reduced or stopped. 


\subsection{Future challenges and perspectives}

There is a huge and increasing worldwide market for caviar, but international trade is difficult due to the strict legislation implemented to protect the endangered group of fish.

There is a risk that other gourmet products may override caviar. To avoid this, it must be ensured that the organoleptic quality of caviar produced in aquaculture is excellent. Furthermore, promoting the product as an extreme delicacy becomes even more important in the future. To avoid misuse of the term caviar, the Codex Alimentarius Commission (CAC) of the Joint FAO/WHO Food Standard Program has decided on a Standard for Sturgeon Caviar (Codex Stan 291 - 2010).

Geosmin is a general problem in RAS but even more so in the production of caviar due to its renowned status as an exquisite delicacy (Kaj Arvonen, Arvotec, pers. comm.; Mogens Larsen, Lyksvad Fiskefarm, pers. comm.). It is therefore of utmost importance that this problem is carefully considered and ultimately eliminated in the farming process.

Systematic breeding programs are needed that select for all female fingerlings (when aiming for caviar production), prevent unnecessary on-growing of males, and reduce the time to maturity (Litvak, 2010).

\section{Nile tilapia (Oreochromis niloticus)}

\subsection{Current status}

There is an increasing interest for rearing tilapia in the Nordic countries, particularly in aquaponic systems where nutrient rich effluent from culture tanks is used for green house production. Several European companies, including a Swedish company, have thus started out with this relatively simple and well-known green growth technology aiming at sustainable productions (e.g., Heeb et al., 2009). Nile tilapia is a relatively fast growing, warm water species, offering new opportunities for RAS productions utilizing waste heat from industries or geothermal heat which is available in many countries. Focus is currently on small urban production units for local food production, but in areas with geothermal heat or stable supply of waste heat the units could become of commercial scale. Current operation costs of tilapia in RAS are high due to the limited production combined with a low fillet yield (about 30-32\%; Ragnheidur Thorarinsdottir, pers. comm.). On the upside, current market prices are relatively high, i.e., about $10-20 € / \mathrm{kg}$ for locally produced fresh fillets. Furthermore, the costs of feed are relatively low, i.e., approximately half the cost of feed for salmonids.

\subsection{Rearing conditions}

Tilapia is a rapidly growing, high-density tolerating species enduring densities up to $120 \mathrm{~kg} / \mathrm{m}^{3}$ making it well suited for aquaculture. It is omnivorous and can therefore feed on both plant and 
animal products in contrast to most other aquaculture species cultured in the Nordic countries, providing opportunities for sustainable productions based on local feed ingredients. A dietary protein content of $32-36 \%$ and $28-32 \%$ is generally recommended for fingerlings and on-growing fish, respectively (Riche and Garling, 2003). The fat content should not exceed $4-8 \%$ in diets for ongrowing fish (Riche and Garling, 2003), while it should be a little higher in feed for fingerlings (Jauncey, 1998).

Given the right conditions, fry may increase their body weight by $50 \%$ every three days (Riche and Garling, 2003), and tilapia may grow to approximately $1 \mathrm{~kg}$ in 8-9 months if reared at a temperature of $27-28{ }^{\circ} \mathrm{C}$ and on a diet containing $30 \%$ protein (Ragnheidur Thorarinsdottir, pers. comm.). It is recommended to feed on-growing tilapia at 4-5 hour intervals to improve feed utilization (Riche and Garling, 2003).

There is currently limited information on water quality parameters for the species in intensive RAS in operation (table 1). The optimal growth temperature ranges between $20-30{ }^{\circ} \mathrm{C}$, and dissolved oxygen concentrations should preferably be maintained above $5 \mathrm{mg} / \mathrm{L}$ at all times for optimal growth. Feeding should be stopped if the level drops below $3 \mathrm{mg} / \mathrm{L}$ (Riche and Garling, 2003). As for other fish species, unionized ammonia should be kept at an absolute minimum (Riche and Garling, 2003). Tilapia has high resistance against pathogens and low mortalities are generally observed.

\subsection{Existing RAS setups}

As mentioned in section 8.1, there are relatively few tilapia producers in Europe, and mostly with relatively small production systems. A brood-stock of Nile tilapia was imported from North American Tilapia Inc. (NATI, Lindsay, Ontario, Canada) to Iceland in 2008 and tested in a RAS at Keldnaholt, Reykjavik. The system had an internal recirculation flow of $600 \mathrm{~L} / \mathrm{min}\left(36 \mathrm{~m}^{3} / \mathrm{h}\right)$, and consisted of a drum filter, combined aerator and low-head oxygenator, and a moving bed biofilter (Johannsson et al., 2009). A commercial scale RAS production of tilapia based on this brood-stock was initiated in 2011, aiming for an annual production of 2,000 MT. The facility consists of a simple, semi-intensive recirculation system (with a degree of recirculation of $70 \%$ ) and no biofiltration. It contains both indoor and outdoor tanks with geothermal heat used to maintain a rearing temperature of $27-28^{\circ} \mathrm{C}$.

\subsection{Future challenges and perspectives}

High capital costs are one of the biggest challenges for economically sustainable RAS production of tilapia in the Nordic countries. The systems must become sustainable in terms of energy utilization and cutting costs further by, e.g., using local feed ingredients.

Aquaponic systems are fetching increasing interest as a potential future technology for safe, local food production, and also polycultures with other species might offer interesting possibilities. 


\section{European lobster (Homarus gammarus)}

\subsection{Current status}

European lobster (Homarus gammarus) is among the most valuable and preferred seafood products. Despite a wide distribution from Northern Norway to Greece, annual landings are just about 2,0002,500 MT (Agnalt, 2008). Norway was one of the major fishing nations for European lobster until 1960, but the annual landings declined by more than $90 \%$ between 1960 and 1980 to around 50 MT (Jørstad et al., 2001). Lobster stocks in Norway have not recovered since then, and the stock is at a historically low and critical level (Agnalt, 2008).

Farming of European lobster in RAS is still in its infancy, but incentives for land-based rearing are large. The species is subject to increasing market prices due to high marked demands and the low and discontinuous wild catches.

\subsection{Rearing conditions}

Information on desirable water quality parameters and rearing conditions for European lobster are generally sparse (table 1). A thorough description of the currently best known rearing conditions and key water quality parameters for intensive production of European lobster in RAS can be found in Drengstig and Bergheim (this issue).

Recent research has shown that it is possible to rear lobster larvae, juveniles and plate-sized lobsters at high intensities, and major progress has been achieved on automation to support commercial rearing of full grow-out cultures (Drengstig et al., 2009). European lobsters can be farmed from hatching to market size (i.e., from approximately $20 \mathrm{~cm}$ to $300 \mathrm{~g}$ ) in 24-30 months (i.e., Drengstig et al., 2003a, 2003b; Kristiansen et al., 2002, 2004; Wickins and Beard, 1991).

Ammonia is quite toxic to lobsters and seems to be the major limiting parameter in recirculation seawater systems, requiring a biological filter to mitigate the toxic effect. Lobster feed is high in protein, and ammonia excretion rates are correspondingly high. Average production rates of $0.1-$ $0.5 \mathrm{~g} \mathrm{TAN} / \mathrm{kg} /$ day have been reported for adult lobster (Drengstig and Bergheim, 2010).

Protein is the main energy source for crustaceans and the diet of wild lobsters contains $40-60 \%$ protein (Leavitt et al., 1979). Crustaceans utilize carbohydrates better than lipids (Ackefors et al., 1992), and lobsters utilize complex carbohydrates better than simple ones (Cuzon and Guillaume, 1997). The optimal dietary DP:DE ratio has not yet been established. However, a formulated diet that can be used from I-stage larvae to market sized lobsters has been developed, substituting the need for live and / or natural feed.

Wild brood-stocks should be quarantined before introduced into a facility and proper water quality, adequate feed, and minimal stress should be ensured. In comparison to other lobster species, 
Homarus species are characterized by a simple and abbreviated larval period. They feed readily on natural and artificial food and exhibit rapid growth in heated water. The optimum growth temperature is $18-20^{\circ} \mathrm{C}$.

European lobsters are generally quite resistant to diseases although they do seem susceptible to Gaffkemia caused by the bacteria Aerococcus viridians homari. Intensive culture does not appear to increase the risk of disease outbreaks, and with over a century of experimental and commercial lobster hatchery operations only a few incidents of diseases have been recorded (Jørstad et al., 2001; Kristiansen et al., 2004). Epizootic shell disease has been observed in some American lobster (Homarus americanus) specimens discovered in Norwegian waters, but transmission to European lobster has not been reported (Jørstad et al., 2001).

\subsection{Existing RAS setups}

European lobster is highly cannibalistic and needs to be reared in separated compartments. Furthermore, the relatively high, optimal rearing temperature requires heating of seawater. Major prerequisites for successful rearing in RAS therefore include development of highly advanced technologies and effective conservation of water. There is currently only one producer farming lobster in land-based RAS from egg to market size, and a detailed description of the system can be found in Drengstig and Bergheim (this issue). The technique has been developed over the last 12 years, aiming at obtaining a viable farming solution and developing a technology that will be economically, biologically, and technically suitable for industrial scale production. The facility consists of a hatchery unit, a brood-stock section, and an on-growing unit. The principle in the technology is that pelagic larvae after hatching (approximately $10 \mathrm{~mm}$ ) are kept in upstream incubators for approximately 14 days. The hatchery facility provides optimum conditions during this stage by simulating the pelagic stage in the wild. After two weeks and three moults, the juveniles (reaching approximately $20 \mathrm{~mm}$ ) turn to benthic condition. At this stage, they are transferred to single cages to prevent cannibalism. The lobsters change cages twice during the grow-out phase according to size. Tanks and individual cages are self-cleaning given specific hydraulics.

\subsection{Future challenges and perspectives}

A genetic tagging program was launched in 2008 as a cooperation project between the Norwegian Lobster Farm AS and the Institute of Marine Research in Bergen, Norway. The overall aim of the program was to develop a genetic databank that can be used for screening and selecting the best performing, wild caught brood-stock by monitoring offspring growth, survival, and feed utilization. The genetic tagging program also included simulating seasonal changes by adjusting the ambient temperature for 2 groups of brood-stock. As a result, it is possible to hatch juveniles from January 
until December, and performance of these juveniles is currently being evaluated. Moreover, successful attempts have been made to breed brood-stock in captivity. Monitoring of juvenile performance was conducted in 2011, but the program was postponed until 2013 due to a fire in the hatchery.

There is currently a lack of knowledge on respiration and excretion rates for lobster at all stages. Based on the economic importance of these issues, current activities are carried out focusing on identifying critical water quality values in order to dimension the technical equipment to sustain a healthy RAS environment.

\section{Discussion}

Applications of RAS seem the most promising road ahead for boosting aquaculture production in the Nordic countries, and there are many ongoing activities and possibilities for culturing different species in RAS. Species that have not been embraced above, but where some preliminary examinations have been carried out include for example common sole (Solea solea), perch (Perca flavescens), turbot (Scopthalmus maximus), and whitefish (Coregonus lavaretus). High capital costs are one of the biggest challenges to sustainable RAS calling for large scale intensive productions to reduce investment and operation costs. Consistent with this, production of Atlantic salmon smolts in indoor RAS and rainbow trout in outdoor MTFs have been the most successful, commercial productions so far. Both of these production systems have: i) arisen from traditional, well known and well established species and industries; ii) comprise large scale, intensive production units; and iii) have had sufficient financial support from the start.

Much of the RAS technology applied is already well known (e.g., Crab et al., 2007; Eding et al., 2006; Martins et al. 2010; Sindilariu et al. 2008; Timmons and Ebeling, 2007). It has been thoroughly tested and is, as such, more or less ready to apply for culturing a variety of species. However, focusing solely on technological solutions, while overlooking associated costs, may be risky and lead to nonprofitable productions.

The technology must be constantly optimized and assessed, and the systems operated and managed accordingly in order to ensure economic viable returns in a fluctuating market. Furthermore, costeffective solutions for end-of-pipe treatment, including sludge handling and efficient nitrogen removal, are still a challenge (Mirzoyan et al. 2010; van Rijn et al. 2006). Here, it may be beneficial to learn from urban waste water treatment processes and management (Pedersen et al., 2012). In addition, it is essential to develop production methods and routines that ensure high product quality and reduce general problems in RAS such as off-flavors caused by for example geosmin and 2methylisoborneol (Houle et al., 2011; Krishnani et al., 2008; Schrader and Summerfelt, 2010; Tucker, 
2000). Treatment of diseases is another ubiquitous issue in RAS. While some diseases might more or less disappear when rearing in RAS, others may aggravate. An example of the latter is white spot disease caused by the protozoan parasite Ichthyophthirius multifiliis. Outbreaks are typically treated with formalin, although less environmentally harmful and health hazardous substances are becoming available (e.g., Pedersen et al., this issue). It is, however, outside the scope of this paper to get further into diseases and disease treatment.

Given that the technology is more or less in place, successful production of "new" fish species in RAS depends largely on identifying biological requirements such as the specific water quality conditions of the specific species including different life-stages, and designing the RAS to fulfill and support these specific requirements. Large scale production of crustaceans in RAS is more challenging, still requiring development and optimization of the necessary technology.

It is a prerequisite for successful RAS production of most species to have well established broodstocks rather than relying on supply from the wild. Cultured brood-stocks reduce the risk of introducing diseases into the systems, ensure a steady (all year round) supply of progeny, and allow for carrying out domestication and breeding programs selecting for desired traits such as enhanced growth and improved feed utilization.

Successful operations of less intensive RAS including aquaponic systems appear to be feasible primarily when culturing more exotic species targeted for selected customers.

\section{Acknowledgements}

We are very grateful to Bjarne Hald Olsen (Billund Aquaculture), Christian Graver (Association of Danish Eel Producers), Martin Vestergaard (Aquapri A/S), Mogens Larsen (Lyksvad Fiskefarm), and Sveinbjorn Oddsson (Islensk matorka ehf.) for their valuable input regarding hands-on experience with constructing and operating different RAS in practice. 


\section{References}

Ackefors, H., Castell, J.D., Boston, L.D., Raty, P., Svensson, M., 1992. Standard experimental diets for crustaceans nutrition research. 2. Growth and survival of juvenile crayfish Astacus astacus (Linne) fed diets containing various amounts of protein, carbohydrates and lipid. Aquaculture 104, $341-$ 356.

Agnalt, A.-L., 2008. Stock enhancement of European lobster (Homarus gammarus) in Norway; Comparisons of reproduction, growth and movement between wild and cultured lobster. Dr. Scient. Thesis, Department of Biology, University of Bergen, Norway.

Bergheim, A., Drengstig, A., Ulgenes, Y., Fivelstad, S., 2009. Production of Atlantic salmon smolts in Europe - Current characteristics and future trends. Aquacult. Eng. 41, 46-52.

Bronzi, P., Rosenthal, H., Gessner, J., 2011. Global sturgeon aquaculture production: an overview. J. Appl. Ichthyol. 27, 169-175.

Buchman, K., Kania, P.W., Neumann, L., de Besi, G., 2011. Pseudodactylogyrosis in Anguilla anguilla (Actinopterygii: Anguilliformes: Anguillidae): change of control strategies due to occurrence of anthelmintic resistence. Acta Ichthyol. Piscat. 4, 105-108.

Colt, J., 2006. Water quality requirements for reuse systems. Aquacult. Eng. 34, 143-156.

Crab, R., Avnimelech, Y., Defoirdt, T., Bossier, P., Verstraete, W., 2007. Nitrogen removal techniques in aquaculture for a sustainable production. Aquaculture 270, 1-14.

Cuzon, G., Guillaume, J., 1997. Energy and Protein: Energy ratio, in: D’Abramo, L.R., Conklin, D.E., Akiyama, D.M. (Eds.), Crustacean nutrition, Advances in World Aquaculture Vol. 6, World Aquaculture Society, Louisiana State University, Baton Rouge, Louisiana, USA, pp. 51-70.

Dalsgaard, J., Pedersen, P.B., 2011. Solid and suspended/dissolved waste (N, P, O) from rainbow trout (Oncorynchus mykiss). Aquaculture 313, 92-99.

Dansk Akvakultur, 2007. Projekt FREA. Udredning af de kommercielle og tekniske muligheder for at opdrætte ørreder i Fuldt REcirkulerede Akvakulturanlæg (FREA) ("in Danish": Evaluation of commercial and technological prospects of rearing trout in fully REcirculated Aquaculture Systems (FREA)). Dansk Akvakultur, Denmark. 24 April 2012 <http://danskakvakultur.dk/images/pdfdokumenter/FREA\%20rapport_1207.pdf>. Dansk Akvakultur, 2008. Samlerapport MMS - Master Management System ("in Danish": Report on the Master Management System MMS). Dansk Akvakultur, Denmark. 
Danish Ministry of Environment, 2012. Bekendtgørelse of miljøgodkendelse og samtidig sagsbehandling af ferskvandsdambrug ("in Danish": Executive order on the environmental approval and handling of freshwater aquaculture systems). Lovtidende A nr. 130. Miljøstyrelsen, Miljøministeriet, Denmark.

Drengstig, A., Bergheim, B., 2012. Commercial land-based farming of European lobster (Homarus gammarus L.) in Recirculating Aquaculture System (RAS) using a single cage approach. Aquacult. Eng. this issue.

Drengstig, A., Bergheim, A., 2010. A pilot RAS for commercial production of European lobster. Aquacultural Engineering Society Proceedings VII, AES Fifth Issues Forum, Roanoke, Virginia, 16-20 August 2010, USA, pp. 178-186.

Drengstig, A., Ulgenes, Y., Liltved, H., Bergheim, A. 2011a. Norwegian salmon smolt farms embracing RAS to raise production. Global Aquaculture Advocate, July/August 2011, 67-69.

Drengstig, A., Ulgenes, Y., Liltved, H., Bergheim, A. 2011b. Recent RAS trends of commercial salmon smolt farming in Norway. Presented at Aquaculture America 2011, New Orleans, Louisiana, USA. Drengstig, A., Drengstig, T., Agnalt, A.-L., Jørstad, K., Farestveit, E., 2009. Utvikling av metoder for stabil produksjon av hummeryngel med gode vekstegenskaper ("in Norwegian": Development of practices for a stable production of lobster juveniles with good growth potentials). Sluttrapport til Vestlandsrådet/Innovasjon Norge, Norwegian Lobster Farm rapport, Norway. 23 April 2012 <http://www.rup.no/vision/vision7.aspx?hierarchyid=763\&type=3>.

Drengstig, A., Drengstig, T., Kristiansen, T.S., Bergheim, A., 2003a. Recent development in lobster farming in Norway - prospects and possibilities. Fish Farmer Magazine, 26 (2): 28-29.

Drengstig, A., Kristiansen, T.S., Drengstig, T., 2003b. Hummer - vår nye marine oppdrettsart? ("In Norwegian": Lobsters - a new marine, aquaculture species?), in: Ervik, A., Skilbrei, O., van der Meeren, T. (Eds.), Havbruksrapporten 2003, Fisken og havet, særnr. 3-2003, Norway, pp. 54-56. Eding, E., Verdegem, M., Martins, M., Schlaman, G., Heinsbroek, L., Laarhoven, B., Ende, S., Verreth, J., Aartsen, F., Bierbooms, V., 2009.Tilapia farming using recirculating aquaculture systems (RAS) case study in the Netherlands. A handbook for sustainable aquaculture. Project no.: COLL-CT-2006030384. 21 April 2012 <http://www.sustainaqua.org/>.

Eding, E.H., Kamstra, A., Verreth, J., Huisman, E.A., Klapwijk, A., 2006. Design and operation of nitrifying trickling filters in recirculating aquaculture: A review. Aquacult. Eng. 34, 234-260.

EU, 2007. Council Regulation (EC) No 1100/2007 of 18 September 2007 establishing measures for the recovery of the stock of European eel. OJEU, 248: 17-23. 
FAO, 2012. Fishery Fact Sheets Collections. Cultured Aquatic Species Information Programme (CASIP). Acipenser baerii (Brandt, 1869). Fisheries and Aquaculture Department, Food and Agriculture Organization of the United Nations (FAO), Rome.

FAO, 2010. The State of World Fisheries and Aquaculture - 2010 (SOFIA). FAO Fisheries and Aquaculture Department, Food and Agriculture Organization of the United Nations (FAO), Rome. FEAP, 2011. Production Report by FEAP Members (2002-2010). The Federation of European Aquaculture Producers (FEAP). 21 April 2012 <http://www.aquamedia.org/>.

Fivelstad, S., Olsen, A., Åsgård, T., Baeverfjord, G., Rasmussen, T., Vindheim, T., Stefansson, S.O., 2003. Long-term sub-lethal effects of carbon dioxide on Atlantic salmon smolts (Salmo salar L.): ion regulation, haematology, element composition, nephrocalcinosis and growth parameters. Aquaculture 215, 301-319.

Fivelstad, S., Olsen, A., Kløften, H., Ski, H., Stefansson, S., 1999. Effects of carbon dioxide on Atlantic salmon (Salmo salar L.) smolts at constant pH in bicarbonate rich freshwater. Aquaculture 178, 171187.

Garcia-Gallego, M., Akharbach, H., 1998. Evolution of body composition of Europeaneels during their growth phase in a fish farm, with special emphasis on the lipid component. Aquacult. Int. 6, 345-356.

Glandfeld, R., 1993. Arctic char production in Ontario, in: Proceedings of the Canadian Arctic Char Conference 93-2, St. Andrews, NB, November, 1992, Bulletin of the Aquaculture Association of Canada.

Gunnarsson, S., Imsland, A.K., Árnason, J., Gústavsson, A., Arnarson, I., Jónsson, J.K., Foss, A., Stefansson, S., Thorarensen, H., 2011. Effect of rearing temperatures on the growth and maturation of Arctic charr (Salvelinus alpinus) during juvenile and on-growing periods. Aquacult. Res. 42, 221229.

Gunnarsson, V.I. 2006. Staða bleikjueldis á Islandi, samkeppnishæfni og stefnumótun rannsókna- og próunarstarfs ("in Icelandic"). (The status of aquaculture of Arctic charr in Iceland, competitiveness and R\&D strategy). Sjávarútvegurinn, vefrit um sjávarútvegsmál, 2 tbl. 6. Árg., Iceland.

Hamlin, H.J., Michaels, J.T., Beaulaton, C.M., Main, K.L., 2006. Refining feeding practices for hatchery production of Siberian sturgeon, Acipenser baeri. J. World Aquacult. Soc. 37, 224-230.

Hansen , I.W., 1997. Eel farming in re-circulation systems. Aquaculture Explained, part 2, pp. 19-20. 
Heeb, J., Wyss, P., Adamek, Z., 2009. Tropical polyculture production with the integrated "Tropenhaus" concept - Case study in Switzerland. A handbook for sustainable aquaculture, pp. 95104. Project no.: COLL-CT-2006-030384. 21 April 2012 <http://www.sustainaqua.org/>.

Hevrøy, E.M., Sandnes, K., Hemre, G.-I., 2004. Growth, feed utilization, appetite and health in Atlantic salmon (Salmo salar L.) fed a new type of high lipid fish meal, Sea Grain ${ }^{\circledR}$, processed from various pelagic marine fish species. Aquaculture 235, 371-392.

Houle, S., Schrader, K.K., Le Francois, N.R., Comeau, Y., Kharoune, M., Summerfelt, S.T., Savoie, A., Vandenberg, G.W., 2011. Geosmin causes off-flavour in arctic charr in recirculating aquaculture systems. Aquacult. Res. 42, 360-365.

Huertas, M., Cerda, J., 2006. Stocking density at early development stages affects growth and sex ratio in the European eel (Anguilla anguilla). Biol. Bull. 211, 286-296.

ICES, 2009a. Report of the ICES Advisory Committee, 2009: Widely distributed and migratory stocks. ICES Advice, Book 9, Copenhagen, pp 1-113.

ICES, 2009b. Report of the 2009 session of the joint EIFAC/ICES Working Group on Eels. Gøteborg, Sweden, 7-12 September 2009. EIFAC Occasional Paper No 45. ICES CM 2009/ACOM: 15.

Jaric, I., Gessner, J., 2012. Analysis of publications on sturgeon research between 1996 and 2010. Scientometrics $90,715-735$.

Jatteau, P., 1997. Daily patterns of ammonia nitrogen output of Siberian sturgeon Acipenser baeri (Brandt) of different body weights. Aquacult. Res. 28, 551-557.

Jauncey, K., 1998. Tilapia feeds and feeding. Pisces Press Ltd., Stirling, Scotland.

Joensen, R., 2008. Resirkulering av vand i opdrett ("in Norwegian": Water recirculation in aquaculture rearing facilities). Presentation at Seminar of Recirculation of Water in Aquaculture, 2728 February 2008, Sunndalsøra, Norway.

Johannsson, R., Thorarensen, H., Ögmundarson, O., 2010. Betri nýting vatns í bleikjueldi (“in Icelandic": Improved water use in Arctic charr aquaculture). Matis report 26-10, Matis, Iceland. Johannsson, R., Timmons, J.E., Holder, J.L., Timmons, M.B., 2009. Water filtration system and its use. United States Patent No US 7,527,730 B2, May 5, 2009.

Johnson, L., 1980. The Arctic charr, Salvelinus aplinus, in: Balon, E.K. (Ed.), Charrs: Salmonid fishes of the genus Salveninus, Dr. W. Junk Publishers, The Hague, Netherlands, pp. 15-98.

Jokumsen, A., Svendsen, L.M., 2010. Farming of freshwater rainbow trout in Denmark. DTU Aqua Research Report no. 219-2010, Technical University of Denmark, Denmark. 
Jørstad, K.E., Agnalt, A.L., Kristiansen T., Nøstvold E., 2001. High survival and growth of European lobster juveniles (Homarus gammarus), reared communally on a natural bottom substrate. Mar. Freshwater Res. 52, 1431-1438.

Köksal, G., Rad, F., Kindir, M., 2000. Growth performance and feed conversion efficiency of Siberian sturgeon juveniles (Acipenser baeri) reared in concrete raceways. Turk. J. Vet. Anim. Sci. 24, 435-442. Krishnani, K.K., Ravichandran, P., Ayyappan, S., 2008. Microbially derived off-flavor from geosmin and 2-methylisoborneol: sources and remediation, in: Whitacre, D.M. (Ed.), Reviews of environmental contamination and toxicology, Springer, pp. 1-27.

Kristensen, T., Åtland, Å., Rosten, T., Urke, H.A., Rosseland, B.O., 2009. Important influent-water quality parameters at freshwater production sites in two salmon producing countries. Aquacult. Eng. 41, 53-59.

Kristiansen, T.S., Drengstig, A., Bergheim, A., Drengstig, T., Svensen, R., Kollsgård, I., Nøstvoll, E. Farestveit, E., Aardal, L., 2004. Development of intensive farming methods for the European lobster (Homarus gammarus L.) in recirculated seawater. Results from experiments conducted at Kvitsøy Lobster Hatchery from 2000 to 2004. Fisken og Havet 6, Institute of Marine Research, Bergen, Norway.

Kristiansen, T.S., Drengstig, A., Drengstig, T., Aardal, L., 2002. New possibilities for farming the European lobster, in: Extended abstract and oral presentation, EAS special publication No. 32, August 2002, Trieste, Italy, pp. 283-284.

Leavitt, D. F., Bayer R. C., Gallaher M. L., Rittenburg J. H., 1979. Dietary intake and nutritional characteristics in wild American lobsters (Homarus americanus). J. Fish. Res. Board Can. 36, 965-969. Le François, N.R., Jobling, M., Carter, C., Blier, P. (eds.), 2010. Finfish Aquaculture Diversification. CABI.

Lekang, O.-I., 2008. Production planning and management of salmon farms. Lecture notes of TAK 251, The Norwegian University of Life Sciences (UMB), Norway.

Linnér, L., Brännäs, E., 2001. Growth in Arctic charr and rainbow trout fed their daily meals concentrated or spread in time. Aquacult. Int. 9, 35-44.

Litvak, M. 2010. The sturgeons (Family: Acipenseridae), in: Le François, N.R., Jobling, M., Carter, C., Blier, P.U. (Eds.), Fisfish aquaculture diversification, CABI, pp. 178-199. 
Lozys, L., 2004. The growth of pikeperch (Sander lucioperca L.) and perch (Perca fluviatilis L.) under different water temperature and salinity conditions in the Curonian Lagoon and Lithuanian coastal waters of the Baltic Sea. Hydrobiologia 514, 105-113.

Luchiari, A.C., de Morais Freire, F.A., Koskela, J., Pirhonen, J., 2006. Light intensity preference of juvenile pikeperch Sander lucioperca (L.). Aquacult. Res. 37, 1572-1577.

Martens, L.G., Witten, P.E., Fivelstad, S., Huysseune, A., Sævareid, B., Vikeså, V., Obach, A., 2006. Impact of high water carbon dioxide levels on Atlantic salmon smolts (Salmo salar L.): Effects on fish performance, vertebrae composition and structure. Aquaculture $261,80-88$.

Martins, C.I.M., Pistrin, M.G., Ende, S.S.W., Eding, E.H., Verreth, J.A.J., 2009. The accumulation of substances in Recirculating Aquaculture Systems (RAS) affects embryonic and larval development in common carp Cyprinus carpio. Aquaculture 291, 65-73.

Martins, C.I.M., Eding, E.H., Verdegem, M.C.J., Heinsbroek, L.T.N., Schneider, O., Blancheton, J.P., d'Orbcastel, E.R., Verreth, J.A.J., 2010. New developments in recirculating aquaculture systems in Europe: A perspective on environmental sustainability. Aquacult. Eng. 43, 83-93.

McCarthy, T.K., O’Farrell, M., McGovern, P., Buckley, P., Copley, L. 1996. Management of juvenile eel stocks for fishery enhancement. Aquaculture Explained, part 1, pp. 7-40.

Mirzoyan, N., Tal, Y., Gross, A., 2010. Anaerobic digestion of sludge from intensive recirculating aquaculture systems: Review. Aquaculture 306, 1-6.

Molleda, M.I., 2007. Water quality in recirculating aquaculture systems for Arctic charr (Salvelinus alpines L.) culture. Final project 2007. The United Nations University Fisheries Training Programme (UNU-FTP).

Mortensen, H., 1996. Sammenligning af 10 recirkulerede åleanlæg ("in Danish": A comparison of 10 recirculated aquaculture systems for rearing of eel). Rapport fra Dansk Akvakultur Center, Denmark. Oddsson, S., Steindorsson, T., 2009. Staða bleikjueldis og framtíðarhorfur ("in Icelandic": Status and future prospects of Arctic char aquaculture). Ministry of Agriculture and Fisheries, Iceland.

Opstvedt, J., Aksnes, A., Hope, B., Pike, I.H., 2003. Efficiency of feed utilization in Atlantic salmon (Salmo salar L.) fed diets with increasing substitution of fish meal with vegetable proteins. Aquaculture 221, 365-379.

Paisley, L.G., Ariel, E., Lyngstad, T., Jonsson, G., Vennerstrom, P., Hellstrom, A., Ostergaard, P., 2010. An Overview of Aquaculture in the Nordic Countries. J. World Aquacult. Soc. 41, 1-17. 
Paschos, I., Perdikaris, C., Gouva, E., Nathanailides, C., 2008. Sturgeons in Greece: a review. Journal of Appl. Ichthyol. 24, 131-137.

Pedersen, L.F., Meinelt, T., Straus, D.L. 2012. Peracetic acid degradation in freshwater aquaculture systems and possible practical implications. Aquacult. Eng. this issue.

Pedersen, L.F., Suhr, K.I., Dalsgaard, J., Pedersen, P.B., Arvin, E. 2012. Effects of feed loading on nitrogen balances and fish performance in replicated recirculating aquaculture systems. Aquaculture 338-341, 237-245.

Pedersen, P.B., Svendsen, L.M., Sortkjær, O., Ovesen, N.B. Skriver, J., Larsen, S.E., Rasmussen, R.S., Dalsgaard, A.J.T. 2008. Environmental benefits achieved by applying recirculation technology at Danish trout farms (Model Trout Farm), in: Proceedings of the Aquacultural Engineering Society's Fourth Issues Forum, Roanoke, Virginia, USA.

Rachek, Y.I., Svirskii, V.G., Skirin, V.I., 2010. Generative and somatic production of female sturgeon at a Research Farm in Primorsky Krai as a basis for manufacturing gastronomic caviar. Russ. J. Mar. Biol. $36,548-561$.

Riche, M., Garling, D. 2003. Feeding tilapia in intensive recirculating systems. North Central Regional Aquaculture Center Fact Sheet Series \#114, NCRAC Publications Office, lowa State University, Ames, USA.

Savin, C., Cristea, V., Talpes, M., Ionescu, T.I., Ion, S., Cristea, D., Oprea, R., 2011. Ammonia control of intensive sturgeon aquaculture. J. Environ. Prot. Ecol. 12, 976-981.

Schrader, K.K., Summerfelt, S.T., 2010. Distribution of off-flavor compounds and isolation of geosmin-producing bacteria in a series of water recirculating systems for rainbow trout culture. $\mathrm{N}$. Am. J. Aquacult. 72, 1-9.

Seymour, E.A., 1989. Devising optimum feeding regimes and temperatures for the warmwater culture of eel Anguilla-anguilla L. Aquacult. Fish. Manage. 20, 311-324.

Siikavuopio, S.I., Skybakmoen, S., Saether, B.S., 2009. Comparative growth study of wild- and hatchery-produced Arctic charr (Salvelinus alpinus L.) in a coldwater recirculation system. Aquacult. Eng. 41, 122-126.

Sindilariu, P.D., Wolter, C., Reiter, R., 2008. Constructed wetlands as a treatment method for effluents; from intensive trout farms. Aquaculture 277, 179-184.

Skybakmoen, S., Siikavuopio, S.I., Sæther, B.S., 2009. Coldwater RAS in an Arctic charr farm in Northern Norway. Aquacult. Eng. 41, 114-121. 
Steenfeldt, S.J., Lund, I., 2008. Udvikling af produktionsmetoder til intensivt opdræt af sandartyngel ("in Danish": Development of methods of production for intensive rearing of pike perch juveniles). DTU Aqua Research Report no. 199-08, Technical University of Denmark, Denmark.

Steenfeldt, S., Vestergaard, M., Overton, J.L., Lund, I., Paulsen, H., Larsen, V.J., Henriksen, N.H., 2010. Videreudvikling af intensivt opdræt af sandart i Danmark ("in Danish": Further development of intensive pike perch rearing in Denmark). DTU Aqua Research Report no. 228-2010, Technical University of Denmark, Denmark.

Summerfelt, S.T., Wilton, G., Roberts, D., Rimmer, T., Fonkalsrud, K., 2004. Developments in recirculating systems for Arctic char culture in North America. Aquacult. Eng. 30, 31-71.

Svavarsson, E., 2007. Árangur af kynbótum á bleikju og næstu skref ("in Icelandic": Achievement and next steps for Arctic charr breeding). Fræđaping landbúnađarins 4, 121-125, Iceland.

Svendsen, L.M., Sortkjær, O., Ovesen, N.B., Skriver, J., Larsen, S.E., Bouttrup, S., Pedersen, P.B., Rasmussen, R.S., Dalsgaard, A.J.T., Suhr, K., 2008. Modeldambrug under forsøgsordningen. Faglig slutrapport for måle- og dokumentationsprojekt for modeldambrug ("in Danish": Model Trout Farms (MTFs) under the MTF pilot project. Final report of the monitoring and documentation program on MTFs). DTU Aqua Research Report no. 193-08, Technical University of Denmark, Denmark.

Terjesen, B.F., Ulgenes, Y., Fjæra, S.O., Summerfelt, S.T., Brunsvik, P., Baeverfjord, G., Nerland, S., Takle, H., Norvik, O.C., Kittelsen, A., 2009. RAS research facility dimensioning and design: A special case compared to planning production systems, in: Proceedings of the Aquacultural Engineering Society's Fourth Issues Forum, Roanoke, Virginia, USA, pp. 223-238.

Timmons, M.B., Ebeling, J.M. 2007. Recirculating Aquaculture. Cayuga Aqua Ventures, Ithaca, NY, USA.

Tomkiewicz, J., Støttrup, J., Sørensen, S.R., Lauesen, P., Munk, P., Jacobsen, C., Kaushik, S., Corraze, G., Tveiten, H., Asturiano, J.F., Pérez, L., McEvoy, F., Graver, C., Johnsen, M.K., Dufour, S., Lafont, A.G., Kjørsvik, E., van Delsen, B., Holst, L.K. 2012. Reproduction of European Eel: Towards a SelfSustained Aquaculture (PRO-EEL). Oral presentation submitted to 6th World Fisheries Congress, 7-11 May 2012, Edinburgh, Scotland. 21 April 2012 <http://www.pro-eel.eu/>.

Tucker C.S., 2000. Off-flavor problems in aquaculture. Rev. Fish. Sci. 8, 45-88.

van Olst, J.C., Carlberg, J.M., Hughes, J.T., 1980. Chapter 10: Aquaculture, in: Cobb, J.S., Phillips, B.F. (Eds.), The biology and management of lobsters, Vol. II, Ecology and management, Academic Press Inc., pp. 333-384. 
Van Rijn, J., Tal, Y., Schreier, H.J., 2006. Denitrification in recirculating systems: Theory and applications. Aquacult. Eng. 34, 364-376.

Wickins, J.F., Beard, T.W., 1991. Variability in size at moult among individual broods of cultured juvenile lobsters. Aquacult. Fish. Manage. 22, 481-489.

Wickins, J.F., Lee, D.O., 2002. Crustacean farming - ranching and culture. Blackwell Science.

Williot, P., Sabeau, L., Gessner, J., Arlati, G., Bronzi, P., Gulyas, T., Berni, P., 2001. Sturgeon farming in Western Europe: recent developments and perspectives. Aquat. Living Resour. 14, 367-374. 
Table 1. Water quality parameters observed under general conditions in operating, commercial or pilot scale RAS

\begin{tabular}{|c|c|c|c|c|c|c|c|c|c|c|}
\hline Parameter & $\begin{array}{l}\text { Temperature } \\
\left({ }^{\circ} \mathrm{C}\right)\end{array}$ & $\begin{array}{l}\mathrm{O}_{2}^{\mathrm{b}} \\
(\mathrm{mg} / \mathrm{L})\end{array}$ & $\begin{array}{l}\mathrm{CO}_{2} \\
(\mathrm{mg} / \mathrm{L})\end{array}$ & pH & $\begin{array}{l}\text { Salinity } \\
\text { (ppt) }\end{array}$ & $\begin{array}{l}\text { TAN } \\
(\mathrm{mg} / \mathrm{L})\end{array}$ & $\begin{array}{l}\mathrm{NO}_{2}-\mathrm{N} \\
(\mathrm{mg} / \mathrm{L})\end{array}$ & $\begin{array}{l}\mathrm{NO}_{3}-\mathrm{N} \\
(\mathrm{mg} / \mathrm{L})\end{array}$ & $\begin{array}{l}\text { Density } \\
\left(\mathrm{kg} / \mathrm{m}^{3}\right)\end{array}$ & References $^{c}$ \\
\hline Arctic char & $5-12$ & $9-11$ & $\leq 22$ & $6.5-8.5$ & $<24-26$ & $\leq 1.0$ & $<0.50$ & $<10$ & $85-130$ & $1-4$ \\
\hline Atlantic salmon smolt & $12-14$ & 10 & $\leq 12$ & $6.8-7.3$ & 0 & $<0.2$ & $<0.20$ & $\leq 90$ & $45-50$ & $5-7$ \\
\hline European eel & $23-28$ & $6-8$ & $10-20$ & $5.0-7.5$ & $0-5$ & $0.0-5.0$ & $0-1.50$ & $50-100$ & $50-120$ & $8-9$ \\
\hline European lobster & $18-20$ & $>6$ & n.a. & $7.8-8.2$ & $28-35$ & $<0.3$ & n.a. & n.a. & n.a. & $10-11$ \\
\hline Pike perch & $22-25$ & $6-8$ & $10-20$ & $6.5-7.5$ & 0 & $0-10.0$ & $0-1.50$ & $\leq 56$ & $15-60$ & $12-13$ \\
\hline Rainbow trout & $2-21$ & $6-8$ & $\leq 15$ & $6.5-8.0$ & $0-30$ & $<7.5$ & $<1.00$ & $<200$ & $50-80$ & $5,14-17$ \\
\hline Sturgeon & $18-25$ & 8 & n.a. & $7.0-8.0$ & 0 & $<3.0$ & $<0.50$ & $<25$ & $80-100$ & $18-23$ \\
\hline Tilapia & $20-30$ & $4-6$ & $\leq 30-50$ & $6.5-8.5$ & $\leq 10-15$ & $<3.0$ & $0.05-1.00$ & $100-200$ & $85-120$ & $1,24-26$ \\
\hline
\end{tabular}

\footnotetext{
${ }^{a}$ The table represents values for commercial or pilot scale RAS for on-growing (excepting Atlantic salmon smolt) as observed primarily by farmers /
} managers. The values may deviate from scientifically validated research results or scientifically determined, optimal physiological values typically obtained under laboratory scale experiments.

${ }^{\mathrm{b}}$ Oxygen concentrations at typical rearing temperatures. 
'Table references: 1. Ragnheidur Thorarinsdottir, Svinna-verkfrædi ehf (pers. comm.); 2. Siikavuopio et al. (2009); 3. Skybakmoen et al. (2009); 4. Summerfelt et al. (2004); 5. Per Bovbjerg Pedersen, DTU Aqua (pers. comm.); 6. Bergheim et al. (2009); 7. Bjarne Hald Olsen, Billund Aquaculture (pers. comm.); 8. Christian Graver, Danish Eel producers Association (pers. comm.); 9. Hansen (1997); 10. van Olst et al. (1980); 11. Wickins and Lee (2002); 12. Martin Vestergaard, Aquapri A/S (pers. comm.); 13. Steenfeldt et al. (2010); 14. Dansk Akvakultur (2008); 15. Pedersen et al. (2012); 16. Peter Vilhelm Skov, DTU Aqua (pers.comm.); 17. Svendsen et al. (2008); 18. Jatteau (1997); 19. Kaj Arvonen, Arvotec (pers. comm.); 20. Köksal et al. (2000); 21. Mogens Larsen, Lyksvad Fiskefarm (pers. comm.); 22. Paschos et al. (2008); 23. Savin et al. (2011); 24. Eding et al. (2009); 25. Sveinbjorn Oddsson, Islensk matorka ehf. (pers. comm.); 26. Timmons and Ebeling (2007). 
Table 2. Average net removal efficiencies $\left(R_{N}, \%\right)^{a}$ of eight Model-Trout-Farms and the concomitant specific discharge (kg/MT fish produced) of nitrogen, phosphorus and $\mathrm{BOD}_{5}$ (Svendsen et al. 2008)

\begin{tabular}{llll}
\hline Nutrient & Total nitrogen & Total phosphorus & BOD $_{5}$ \\
\hline $\mathrm{R}_{\mathrm{N}}$ obtained $(\%)$ & 50 & 76 & 93 \\
Specific discharged $(\mathrm{kg} / \mathrm{MT}$ fish produced) & 20.0 & 1.1 & 5.6 \\
\hline${ }^{\mathrm{a}} \mathrm{R}_{\mathrm{N}}(\%)=\left(\left(\mathrm{P}-\mathrm{U}_{\mathrm{N}}\right) / \mathrm{P}\right) * 100$, where $\mathrm{P}=$ contribution of a given nutrient from fish production
\end{tabular}

(Dalsgaard and Pedersen, 2011), and $U_{N}=$ net discharge of a nutrient from the farm (i.e., discharge concentration minus the contribution from intake water). 